\title{
MARs Wars: heterogeneity and clustering of DNA-binding domains in the nuclear matrix
}

\author{
Y. S. Vassetzky ${ }^{1,2}$, E. S. Ioudinkova ${ }^{3}$, S. V. Razin ${ }^{3}$ \\ ${ }^{1}$ CNRS UMR8126, Universite Paris Sud 11, Institut de Cancerologie Gustave Roussy \\ Villejuif, F-94805 France \\ ${ }^{2}$ N. K. Koltzov Institute of Developmental Biology, Russian Academy of Sciences \\ 26, Ui. Vavilova, Moscow, Russian Federation, 119334 \\ ${ }^{3}$ Institute of Biology of the Gene, Russian Academy of Sciences \\ 34/5, Ul. Vavilova, Moscow, Russian Federation, 119334 \\ vassetzky@igr.fr
}

\begin{abstract}
Aim. CO326 is a chicken nuclear scaffold/matrix attachment region (MAR) associated with the nuclear matrix in several types of chicken cells. It contains a binding site for a sequence-specific DNA-binding protein, F326. We have studied its interaction with the nuclear matrix. Methods. We have used an in vitro MAR assay with isolated matrices from chicken HD3 cells. Results. We have found that an oligonucleotide binding site for the F326 inhibits binding of the CO326 to the nuclear matrix. At the same time, the binding of heterologous MARs is enhanced. Conclusions. Taken together, these data suggest that there exist several classes of MARs and MAR-binding domains and that the MAR-binding proteins may be clustered in the nuclear matrix.
\end{abstract}

Keywords: nuclear matrix, DNA-protein interactions, MAR, SAR.

Introduction. Chromatin of interphase eukaryotic nuclei and metaphase chromosomes is compacted into large loops (for review see $[1,2]$ ). The loops are fixed onto a proteinaceous skeletal structure designated as the nuclear skeleton, scaffold, or matrix [3]. Positions of the anchorage sites of the DNA loops on the nuclear matrix were shown to be non-random, and were mapped in many species ranging from yeast to man (for review see $[4,5])$.

A simple method has been developed for mapping nuclear matrix attachment sites in cloned DNA using an in vitro binding assay. The method is based on binding in vitro of labelled DNA fragments to the isolated nuclear matrix. In the presence of non-specific competitor DNA, only DNA fragments that possess a

(C) Institute of Molecular Biology and Genetics NAS of Ukraine, 2009 high affinity for the nuclear matrix bind. These fragments were designated as Matrix Association Regions or «MARs» [6] or Scaffold Attachment Regions or «SARs» [7]. In the modern literature MARs and SARs are often called S/MARs, according to the suggestion of Bode [8]. In some cases MARs are indeed attached to the nuclear matrix in vivo [9]. However many MARs reside in loop DNA and can be easily extracted from nuclei pre-treated with nucleases [10].

While in vivo function of MARs is not clear, it has been shown that they stimulate replication of plasmids in yeasts [11] and of episomal DNA in cells of higher eukaryotes [12], are necessary for correct expression of immunoglobulin genes [13], and for integration siteindependent expression of genes (for review see [14]). It is generally believed that most MARs mapped using 
$A$

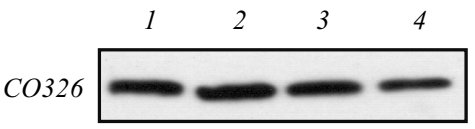

$S / M A R$

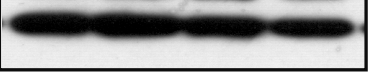

Control

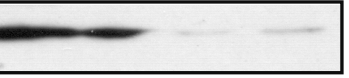

$B$

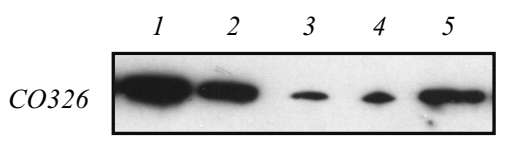

Control

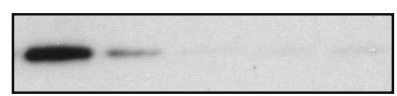

$C$
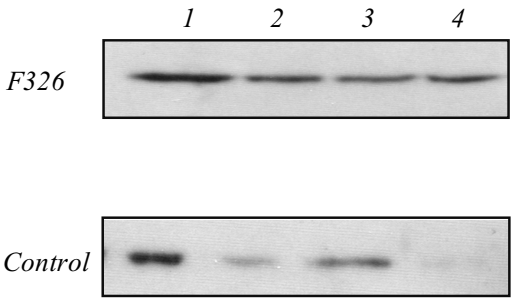

Fig. 1. $A-\mathrm{CO} 326$ fragment has an S/MAR activity. End-labelled CO326 fragment and a mixture of control end-labelled DNA fragments, one of which contained a chicken MAR, were added to the isolated nuclear matrices along with the unlabelled competitor DNA as described in the «Methods» section, incubated at room temperature for $2 \mathrm{~h}$ and washed with the incubation buffer. Matrix-bound DNA was purified by phenol extraction, electrophoretically separated in a polyacrylamide gel and autoradiographed. $1-50 \%$ of the input DNA; $2-4-$ incubation of the labelled DNA in the presence of sonicated salmon sperm DNA added as a competitor $(0,0.5,0.1 \mathrm{and} 0.25 \mathrm{mg} / \mathrm{ml}$, respectively); $B-$ the F326 oligonucleotide binding site efficiently competes with the CO236 S/MAR. End-labelled CO326 fragment and a control end-labelled DNA fragment with no affinity to the nuclear matrix were added to the nuclear matrices along with the unlabelled competitor DNA as described in the «Methods» section, incubated at room temperature for $2 \mathrm{~h}$ and washed with the incubation buffer. Matrix-bound DNA was purified by phenol extraction, electrophoretically separated in a polyacrylamide gel and autoradiographed. $1-50 \%$ of the input DNA; $2-$ incubation of the labelled DNA in the presence of sonicated salmon sperm DNA added as a competitor $(0.25 \mathrm{mg} / \mathrm{ml})$; $3-\mathrm{same}$ as 2 , but a 25 fold molar excess of the oligonucleotide containing binding site for F326 was added as a competitor along with the salmon sperm DNA; 4 the same as 2, but a 50-fold molar excess of the oligonucleotide containing binding site for F326 was added as a competitor along with the salmon sperm DNA. Arrows indicate the positions of the control MAR and the CO326 DNA; 5 - the same as 2, but a 50-fold molar excess of a heterologous oligonucleotide (5'-TATTTGATAGCAATATTTAGTATTT-3') was added as a competitor along with the salmon sperm DNA; $C$ - The F326 oligonucleotide binds to the nuclear matrix. End-labelled F326 oligonucleotide and the control end-labelled oligonucleotide (5'-TATTTGATAGCAATATTTAGTATTT-3') were added to the nuclear matrices along with the unlabelled competitor DNA as described in the «Methods» section, incubated at room temperature for $2 \mathrm{~h}$ and washed with the incubation buffer. Matrix-bound DNA was purified by phenol extraction, electrophoretically separated in a polyacrylamide gel and autoradiographed. $1-50 \%$ of the input DNA; $2-4-$ incubation of the labelled DNA in the presence of sonicated salmon sperm DNA added as a competitor $(0,0.1,0.25$ and $0.05 \mathrm{mg} / \mathrm{ml}, \mathrm{respectively)}$

the in vitro assay are functionally equivalent and evolutionarily conserved [15]. This statement is obviously in contradiction with the diversity of functions attributed to MARs (for review see [5]). We have decided to explore the extent of diversity in known SAR/MAR elements using the classical in vitro MAR assay.

Earlier we have cloned several chicken DNA fragments attached to the nuclear matrix in the nuclei of chicken erythrocytes. One of these MARs designated as $\mathrm{CO} 326$ was shown to interact with a sequencespecific DNA-binding protein F326 which recognised a motif TCACTGCAGACCGCTTCG [16, 17].

In the present study, we addressed the question of functional heterogeneity of MARs by using the in vitro MAR assay using other known MARs and the oligonucleotide binding site for the F326 protein. We have shown that the protein is involved in binding of the CO326 MAR to the nuclear matrix. At the same time, binding of heterologous MARs is enhanced in the presence of an oligonucleotide harbouring F326 binding site suggesting the structural and functional heterogeneity of the nuclear matrix binding sites in the chromatin.

Materials and Methods. Cells and tissues. AEVtransformed chicken erythroblasts HD3 were cultured as described [18].

Plasmids and oligonucleotides. The $\mathrm{CO} 326$ fragment was excised from the CO326-pTZ construct [17] by BamHI digestion. Double-stranded oligonucleotides 5'-GATCCTCACTGCAGACCGCTTCG-3' (F326) and 5'-TATTTGATAGCAATATTTAGTATTT-3' (control) were ordered from Operon (Germany) as complementary single-stranded oligonucleotides and then annealed according to the manufacturer's protocol.

The isolation of nuclear matrices and the MAR assay was carried out essentially as described $[6,19]$. In short, nuclear matrices were prepared by incubation of isolated nuclei from the HD3 cells with DNase I and 
$A$

Beta-interferon S/MAR

Control

$B$

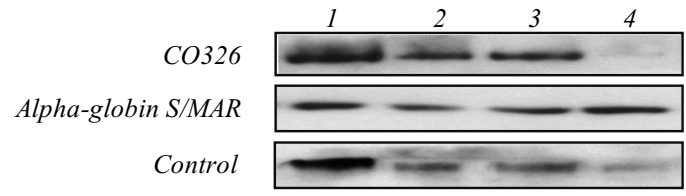

Fig. 2. $A-$ F326 oligonucleotide increases binding of heterologous $\mathrm{S} / \mathrm{MARs}$ to the nuclear matrix in vitro. MAR assay of the human MAR from the beta-interferon gene domain [21]. End-labelled control DNA, CO326 DNA, and either a S/MAR from the beta-interferon gene domain $(A)$ or a S/MAR from the chicken alpha-globin gene domain $(B)$ were added to the isolated nuclear matrices along with the unlabelled competitor DNA as described in the «Methods» section, incubated at room temperature for $2 \mathrm{~h}$ and washed with the incubation buffer. Matrix-bound DNA was purified by phenol extraction, electrophoretically separated in a polyacrylamide gel and autoradiographed. $1-5 \%$ of the input DNA; 2 - incubation of the labelled DNA in the presence of sonicated salmon sperm DNA added as a competitor $(0.25 \mathrm{mg} / \mathrm{ml}) ; 3$ - same as 2 , but a 25 -fold molar excess of the oligonucleotide binding site for F326 was added as a competitor along with the salmon sperm DNA; 4 - the same as 2, but a 50-fold molar excess of the oligonucleotide binding site for F326 was added as a competitor along with the salmon sperm DNA

a subsequent extraction with $2 \mathrm{M} \mathrm{NaCl}$. Fifty nanograms of end-labelled DNA fragments and different amounts of unlabelled competitor DNA (sonicated salmon sperm DNA) were added to nuclear matrices isolated from $2 \cdot 10^{7}$ cells, and incubated at a room temperature for $2 \mathrm{~h}$ in a buffer containing $50 \mathrm{mM} \mathrm{NaCl}, 10 \mathrm{mM}$ Tris-HCl, pH 7.4, 2 mM EDTA, 0.25 mM sucrose; then the non-bound DNA was removed by repeated washing with the incubation buffer. Nuclear matrices were digested by overnight treatment with SDS and proteinase K. Matrix-bound DNA was purified by phenol extraction and the initial complete set of labelled DNA fragments was compared to the matrix-bound and nonbound DNA fractions by electrophoresis in agarose or polyacrylamide gels followed by auto-radiography. In some experiments, a double-stranded oligonucleotide binding site for a nuclear matrix protein F326 [17] (5'-GATCCTCACTGCAGACCGCTTCG-3') was added as a competitor.

Results and Discussion. A nuclear matrix DNA fragment containing the F326 binding site specifically binds to the nuclear matrix in an in vitro assay. To study the role of the F326 protein in attachment of DNA to the nuclear matrix we have used an in vitro S/MAR assay. The CO326 S/MAR was end-labelled and mixed with the equal molar amounts of plasmid DNA with no affinity for the nuclear matrix as a negative control and the well-studied chicken S/MAR from the domain of alpha-globin genes [20]. The mixture of DNA fragments was incubated with the nuclear matrix preparations in the presence of increasing concentrations of competitor DNA, as described in the «Methods» section. After incubation, the matrices were washed with several volumes of the incubation buffer to remove the non-bound probe, and the matrix-bound DNA was recovered by proteinase digestion of the matrix. The pattern of input and matrix-bound labelled DNA were compared by electrophoresis.

Indeed, both the CO326 S/MAR and the control S/MAR (was preferentially associated with the nuclear matrix while the control fragment, had a much less affinity to the nuclear matrix. Thus, the data obtained demonstrate that the studied fragment contains an in vitro S/MAR activity (Fig. 1, $A$ ).

Oligonucleotide containing binding site for the F326 protein binds to the isolated nuclear matrix and inhibits binding of the CO326 S/MAR to the nuclear matrix. Next we checked whether the F326 binding site is necessary for attachment to the nuclear matrix by competing the binding of the CO326 S/MAR to the nuclear matrix with the oligonucleotide containing the binding site for the F326 protein. The MAR assay carried out in the presence of the $25 \mathrm{bp}$-long doublestranded oligonucleotide demonstrated that its 50-fold molar excess completely inhibited binding of the $500 \mathrm{bp}$-long S/MAR to the nuclear matrix (Fig. 1, B). In order to find out whether the observed effect was determined by specific or non-specific competition, we have tried to compete the CO326 S/MAR using a doublestranded oligonucleotide that had no homologies with the studied S/MAR (5'-TATTTGATAGCAATATTTAGTATTT-3'). No significant competition was observed (Fig. 1, B). The above observations strongly suggest that the F326 protein most probably mediates DNA attachment to the nuclear matrix.

A competition between the CO326 S/MAR and the F326 oligo suggests that latter also interacts with the 


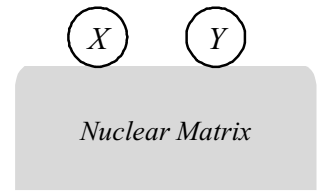

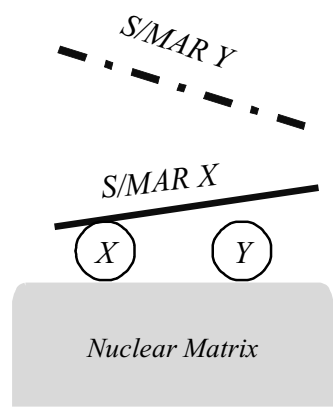

C

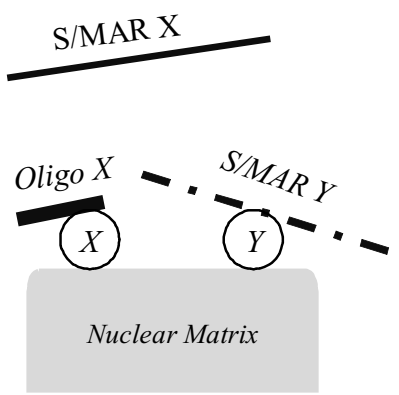

Fig. 3. A model of interaction between MARs and the cluster of DNA-binding matrix proteins: $A$ - the S/MAR binding proteins are clustered in the nuclear matrix; $B$ - binding of one S/MAR $(X)$ would prevent association of a heterologous S/MAR $(Y)$ with the nuclear matrix because of the proximity of S/MAR binding proteins; $C$ - binding of a small oligonucleotide containing the protein $X$ binding site (oligo $X$ ) would inhibit binding of the homologous S/MAR X, but would not interfere with binding of the heterologous S/MAR $Y$, thus increasing the efficiency of its interaction with the nuclear matrix as compared to the case $B$

isolated nuclear matrix. We checked this directly using the in vitro MAR assay. Indeed, the F326 preferentially bound to the nuclear matrix as compared to the control double-stranded oligonucleotide (5'-TATTTGATAGCAATATTTAGTATTT-3'; Fig. 1, C).

Oligonucleotide containing binding site for the F326 protein enhances binding of heterologous MARs to the nuclear matrix. The above results suggest that the F326 protein may participate in organization of DNA-binding sites on the nuclear skeleton. It is known that some MARs of different origin compete with each other in the MAR assay $[6,15]$. In order to check whether the oligonucleotide containing the binding site for the F326 protein can efficiently compete with S/MARs of different origin, we have carried out a MAR assay with the CO326 S/MAR and either the S/MAR from the domain of chicken alpha-globin genes or a S/MAR from the 5'-end of the human betainterferon gene domain [21]. In this experiment, F326 oligo inhibited binding of the CO326 S/MAR to the nuclear matrix, but surprisingly, no competition between the oligonucleotide and above-mentioned MARs was observed, moreover the binding of both S/MARs to the nuclear matrix was enhanced 2-4 fold by a $25 x-50 \times$ molar excess of the F 326 oligonucleotide (Fig. 2).

The above data are obviously in contradiction with the idea that all MARs are structurally the same and, hence, compete for binding to the nuclear matrix, because if it was so, the F326 oligonucleotide would compete with another MAR to a similar extent as the CO326 S/MAR itself. One of the possible explanations is the existence of a cluster of DNA-binding proteins in the nuclear matrix. In this case, two MARs would compete not for the same protein, but for a place in a cluster. Oligonucleotide that binds to one protein in a cluster will inhibit binding of a homologous MAR while exerting no influence or even increasing the binding of a heterologous MAR (Fig. 3).

This explanation assumes that S/MARs are structurally heterologous. Indeed, there are data that both transcription and replication is accomplished at the nuclear skeleton [22]. At the same time, the interaction between DNA and the nuclear matrix also exists in transcriptionally inactive nuclei or genomic domains [23, 24]. These different types of interaction may be mediated by different specific DNA-binding matrix proteins. These proteins may include DNA topoisomerase II, MeCP2 [25], a chicken matrix attachment region protein $[26,27]$ or human tissue-specific MAR binding proteins SATB1 [28] or SATB2 [29].

Further studies will help us to understand in more details the nature of MARs and their interaction with DNA-binding matrix proteins.

Acknowledgements. This research has been supported by grants from the Association Francaise contre les Myopathies (AFM), the Fondation de 
France, the INCa to YSV, PICS 3207 to YSV and SVR, and a MCB grant from the Presidium of the Russian Academy of Sciences to SVR.

\section{С. С. Васеиький, О. С. Юдінкова, С. В. Разін}

Білки, які опосередковують прикріплення ДНК до ядерного матриксу, гетерогенні і утворюють кластери

Резюме

Мета. СО326, ділянка прикріплення до ядерного матриксу, містить сайт зв'язування з ДНК-зв'язувальним білком F326. Методи. Для аналізу матриксу, виділеного з клітинної лінії HD3, використано in vitro MAR-метод. Результати. Олігонуклеотид, який містить сайт зв'язування білка F326, інгібує зв 'язування СО326 з ядерним матриксом, при цьому асоціація гетерологічних ділянок прикріплення до ядерного матриксу зростає. Выводы. Одержані дані свідчать про те, що різні ДНК-зв 'язувальні білки утворюють кластери у ядерному матриксі.

Ключові слова: ядерний матрикс, взаємодія ДНК-білок, $M A R, S A R$.

\section{Е. С. Васеикий, Е. С. Юдинкова, С. В. Разин}

Белки, опосредующие прикрепление ДНК к ядерному матриксу, гетерогенны и образуют кластеры

Резюме

Цель. СО326, участок прикрепления к ядерному матриксу, содержит сайт связывания с ДНК-связывающим белком F326. Mетоды. Для анализа матрикса, выделенного из клеточной линии HD3, использован in vitro MAR-метод. Результаты. Олигонуклеотид, содержащий сайт связывания белка F326, ингибирует связывание СОЗ26 с ядерным матриксом, при этом ассоииация гетерологичных участков прикрепления $\kappa$ ядерному матриксу увеличивается. Выводы. Полученыье данные свидетельствуют о том, что различные ДНК-связываюшче белки образуют кластеры в ядерном матриксе.

Ключевые слова: ядерный матрикс, взаимодействие ДНКбелок, MAR, SAR.

\section{REFERENCES}

1. Vassetzky Y., Lemaitre J. M., Mechali M. Specification of chromatin domains and regulation of replication and transcription during development // Crit. Rev. Eukaryot. Gene Exp.-2000.-10, N 1.-P. 31-38.

2. Razin S. V., Iarovaia O. V., Sjakste N., Sjakste T., Bagdoniene L., Rynditch A. V., Eivazova E. R., Lipinski M., Vassetzky Y. $S$. Chromatin domains and regulation of transcription // J. Mol. Biol.-2007.-369, N 3.-P. 597-607.

3. Razin S. V., Hancock R., Iarovaia O., Westergaard O., Gromova I., Georgiev G. P. Structural-functional organization of chromosomal DNA domains // Cold Spring Harbour Symp. Quant. Biol.-1993.-58.-P. 25-35.

4. Razin S. $V$. The nuclear matrix and spatial organization of chromosomal DNA domains.-Austin, 1997.-195 p.
5. Vassetzky Y. S., Hair A., Razin S. V. Rearrangement of chromatin domains in cancer and development // J. Cell Biochem.-2000.-S35, suppl.-P. 54-60.

6. Cockerill P. N., Garrard W. T. Chromosomal loop anchorage of the kappa immunoglobulin gene occurs next to the enhancer in a region containing topoisomerase II sites // Cell.1986.-44, N 2.-P. 273-282.

7. Mirkovitch J., Mirault M. E., Laemmli U. K. Organization of the higher-order chromatin loop: specific DNA attachment sites on nuclear scaffold // Cell.-1984.-39, N 1.-P. 223-232.

8. Bode J., Stengert-Iber M., Kay V., Schlake T., Dietz-Pfeilstetter $A$. Scaffold/matrix-attached regions: topological switches with multiple regulatory functions // Crit. Rev. Euka-ryot. Gene Exp.-1996.-6, N 2-3.-P. 115-138.

9. Iarovaia O., Hancock R., Lagarkova M., Miassod R., Razin S. $V$. Mapping of genomic DNA loop organization in a 500-kilobase region of the Drosophila X chromosome by the topoisomerase II-mediated DNA loop excision protocol // Mol. Cell. Biol.-1996.-16, N 1.-P. 302-308.

10. Hempel K., Stratling $W . H$. The chicken lysozyme gene 5'MAR and the Drosophila histone SAR are electroelutable from encapsulated and digested nuclei // J. Cell. Sci.-1996.109, pt 6.-P. 1459-1469.

11. Amati B., Pick L., Laroche T., Gasser S. M. Nuclear scaffold attachment stimulates, but is not essential for ARS activity in Saccharomyces cerevisiae: analysis of the Drosophila $\mathrm{ftz}$ SAR // EMBO J.-1990.-9, N 2.-P. 4007-4016.

12. Baiker A., Maercker C., Piechaczek C., Schmidt S. B., Bode $J$., Benham C., Lipps H. J. Mitotic stability of an episomal vector containing a human scaffold/matrix-attached region is provided by association with nuclear matrix // Nat. Cell Biol.-2000.-2, N 3.-P. 182-184.

13. Webb C., Zong R. T., Lin D., Wang Z., Kaplan M., Paulin Y., Smith E., Probst L., Bryant J., Goldstein A., Scheuermann R., Tucker $P$. Differential regulation of immunoglobulin gene transcription via nuclear matrix-associated regions // Cold Spring Harbour Symp. Quant. Biol.-1999.-64.-P. 109-118.

14. Harraghy N., Gaussin A., Mermod N. Sustained transgene expressionf using MAR elements // Curr. Gene Ther.-2008.8, N 5.-P. 353-366.

15. Cockerill P. N., Garrard W. T. Chromosomal loop anchorage sites appear to be evolutionarily conserved // FEBS Lett.1986.-204, N 1.-P. 5-7.

16. Bogdanova A. N., Razin S. V., Vassetzky Y. S. Nuclear matrixassociated DNA fragments enhance autonomous replication of plasmids in chicken cells // Biochimie.-1995.-77, N 11.P. 880-887.

17. Vassetzky Y. S., Bogdanova A. N., Razin S. V. Analysis of the chicken DNA fragments that contain structural sites of attachment to the nuclear matrix: DNA-matrix interactions and replication // J. Cell Biochem.-2000.-79, N 1.-P. 1-14.

18. Beug H., von Kirchbach A., Doderlein G., Conscience J. F., Graf T. Chicken hematopoietic cells transformed by seven strains of defective avian leukemia viruses display three distinct phenotypes of differentiation // Cell.-1979.-18, N 3.- P. 375-390.

19. Gasser S. M., Vassetzky Y. S. Analysis of nuclear scaffold attachment regions, in chromatin: a practical approach / Ed. H. Gould.-Oxford: Oxford Univ. press, 1998.-P. 111-124.

20. Razin S. V., Kekelidze M. G., Lukanidin E. M., Scherrer K., Georgiev G. P. Replication origins are attached to the nuclear skeleton // Nucl. Acids Res.-1986.-14, N 20.-P. 8189-8207. 
21. Klehr D., Maass K., Bode J. Scaffold-attached regions from the human IFN-beta domain can be used to enhance the stable expression of genes under the control of various promoters // Biochemistry.-1991.-30, N 5.-P. 1264-1270.

22. Cook P. R. The organization of replication and transcription // Science.-1999.-284, N 5421.-P. 1790-1795.

23. Linnemann A. K., Krawetz $S$. A. Silencing by nuclear matrix attachment distinguishes cell-type specificity: association with increased proliferation capacity // Nucl. Acids Res.2009.-37, N 9.-P. 2779-2788.

24. Vassetzky Y., Hair A., Mechali M. Rearrangement of chromatin domains during development in Xenopus // Genes Develop.-2000.-14, N 12.-P. 1541-1552.

25. Eivazova E. R., Gavrilov A., Pirozhkova I., Petrov A., Iarovaia O. V., Razin S. V., Lipinski M., Vassetzky Y. S. Interaction in vivo between the two matrix attachment regions flanking a single chromatin loop // J. Mol. Biol.-2009.-386, N 4.P. 929-937.

26. Von Kries J., Buhrmester H., Stratling W. H. A matrix/scaffold attachment region binding protein: identification, purification, and mode of binding // Cell.-1991.-64, N 1-P. 123135.
27. Von Kries J. P., Buck F., Stratling $W$. H. Chicken MAR binding protein P120 is identical to human heterogeneous nuclear ribonucleoprotein (hnRNP) U // Nucl. Acids Res.-1994.22, N 7.-P. 1215-1220.

28. Han H. J., Russo J., Kohwi Y., Kohwi-Shigematsu T. SATB1 reprogrammes gene expression to promote breast tumour growth and metastasis // Nature.-2008.-452, N 7184.-P. 187193.

29. Britanova O., Akopov S., Lukyanov S., Gruss P., Tarabykin $V$. Novel transcription factor Satb2 interacts with matrix attachment region DNA elements in a tissue-specific manner and demonstrates cell-type-dependent expression in the developing mouse CNS // Eur. J. Neurosci.-2005.-21, N 3.P. 658-668. 